\title{
Attitudes of EFL Teachers towards Using Smartphones in the Classroom during COVID-19 Pandemic
}

\author{
Khaled A. Dweikat ${ }^{1, *}$, Hanan A. Hasan ${ }^{2}$ \\ ${ }^{1}$ Faculty of Educational Sciences, Al-Quds Open University, Nablus, Palestine \\ ${ }^{2}$ Ministry of Education, Jenin Directorate of Education, Palestine
}

Received November 7, 2020; Revised December 19, 2020; Accepted January 20, 2021

\section{Cite This Paper in the following Citation Styles}

(a): [1] Khaled A. Dweikat, Hanan A. Hasan, "Attitudes of EFL Teachers towards Using Smartphones in the Classroom during COVID-19 Pandemic," Universal Journal of Educational Research, Vol. 9, No. 1, pp. 116 - 128, 2021. DOI: 10.13189/ujer.2021.090113.

(b): Khaled A. Dweikat, Hanan A. Hasan (2021). Attitudes of EFL Teachers towards Using Smartphones in the Classroom during COVID-19 Pandemic. Universal Journal of Educational Research, 9(1), 116 - 128. DOI: 10.13189/ujer.2021.090113.

Copyright $\bigcirc 2021$ by authors, all rights reserved. Authors agree that this article remains permanently open access under the terms of the Creative Commons Attribution License 4.0 International License

\begin{abstract}
Literature on smartphone technology indicates that smartphones nowadays are almost accessible to everyone with a high percentage even in the least developing countries like Palestine. This accessibility might be due to the various applications, functions and features of the new generations of the smartphones. Hence, the current study aimed to investigate the attitudes of EFL teachers towards using smartphones in the classroom among Palestinian secondary students during COVID-19 pandemic. The study also aimed to find the influence of teachers' gender, years of experience, qualification and the grades the teachers teach on their attitudes. To achieve the objectives of the study, 58 male and female EFL teachers were surveyed through a five-point scale questionnaire and a focus group using Zoom. Results revealed that the attitudes of EFL teachers were moderately positive and that there were no statistically significant differences between the teachers' attitudes due to teachers' gender, years of experience, qualification and the grades the teachers teach. These results shed some light on the readiness of Palestinian EFL teachers to update their methods of teaching and to cope with the ongoing challenges imposed by Coronavirus pandemic.
\end{abstract}

Keywords Attitudes, Smartphones, EFL Teachers, Mall, COVID-19 Pandemic

\section{Introduction}

More than two decades ago, Zehr [1] highlighted the role of public schools in preparing students for the information age through employing more hardware and software which pave the way for connecting classrooms to the Internet. Such role would not be significant without investing in the new trends of technological advancements that can be used in the educational setting. Currently, under the ongoing pandemic of COVID-19, outstanding global investment is being made to employ more advanced technologies in the educational process. Most educational institutions, furthermore, are working hard to integrate mobile learning into their institutions to meet the growing needs and interests of the new generations of students especially nowadays, when e-learning, distance learning, virtual learning, and flipped learning, to name a few, are being used all over the world. This might be due to the fact that today's technology tends to revolutionize the way the youth access information, communicate, give and take help, and learn [2]. Technology, furthermore, can enable active student involvement with interactive content that can be accessed anytime, anywhere [3].

In today's educational systems, where the new modes of communication have attracted significant attention all over the world, schools are also considered significant social spaces where different kinds of materials and practices define modes of engagement and learning [4] and also increasingly bound up with new media such as 
smartphones and other mobile devices [5] and [6]. In this regard, some scholars hold positive views regarding the new teachers who have grown up with technology around them which is hoped to increase the use of technology at school [7] because thinking about technology integration and mobile learning in public schools cannot be separated from our thinking [8]. Thus, a special focus should be given to new trends and approaches that cope with the new forms of Information and communication technology (ICT) such as blended learning, distance learning, e-learning, mobile learning and mobile assisted language learning (MALL) and so forth.

These trends and changes are placing increasing pressure on the traditional methods of teaching and learning which might be attributed to the ever-increasing and diversified needs of the students on one hand and to the large number of technological advancements and their quality emerging every day if not every hour, on the other hand [9]. Consequently, technologies that are connected to computers, Internet and telephone have become the focus of most of educational studies in recent times [10].

One of the latest educational trends that invest in ICT over the last three decades is mobile learning (m-learning) which involves the acquisition of any knowledge or skill through using mobile technology, anywhere, anytime [1]. It also involves connectivity for downloading, uploading and/or online working via wireless networks, mobile phone networks or both [12].

While Schroeder [13] defines mobile learning as learning that takes place via a wireless mobile device, such as mobile phones or laptop computer,[9] connects m-learning to the provision of education and training involving portable or mobile devices such as smartphones, Personal Digital Assistants (PDAs) palmtops, iPads, digital cameras, pocket computers, mobile phones and the like. Hence, m-learning tends to be advantageous since it has the potential to break temporal and spatial lines in addition to placing educative resources to suit students' most favorable methods of learning in this era[14]. According to [15] and [16], m-learning has five main features that involve portability, accessibility, personalization, social connectivity, and using mobile phones to increase motivation. Meanwhile, El Hariry [17] listed the following advantages of mobile phones: personalizing learners' environment, providing learning experience outside the classroom, making learning enjoyable, helping in boosting the morale of the learners, and providing means of accessing materials and knowledge.

Hashemi et al., [12] maintained that the past 10 years have witnessed an increasing development of mobile phone technology which has shifted from plain and simple cell phones to the current high-tech phones which can serve as a mini-computer, a telephone, or a camera, and transfer data as well as video and audio files. Traxler [18] claimed that whatever our reservations about terminology are, mobile learning has often been characterized by its fourfold capacity to extend education, to enrich education, to challenge educational theory and to engage learners. In this respect, mobile learning offers modern ways to support learning process through mobile devices, such as handheld and tablet computers, MP3 players, smartphones and mobile phones [18]. Thus, mobile learning is believed to involve young adults in learning, where more traditional methods have failed [12].

As a result of the various advantages and features of mobile phones, the number of mobile phone users is increasing rapidly in all countries around the world and Palestine is not an exception. In 2014, 73.7\% of the Palestinians owned a mobile phone according to the Palestinian Central Bureau of Statistics [19]. The Household Survey on Information and Communications Technology held on the occasion of the International Population Day on the $7^{\text {th }}$ of November 2020 showed that $97 \%$ of the households in Palestine have one or more cellular mobile lines and $86 \%$ own one smart phone or more. The results also indicated that the percentage of individuals (10 years and above) who own a cellular mobile was $75 \%$ [20]. In USA, a survey conducted in January 2019 showed that $96 \%$ of the Americans owned a cellphone of some kind and $81 \%$ owned a smartphone [21].

In today's world where people are addicted to different types of ICT, mobile phones are making our lives easier and it has become very hard to imagine our life without mobile phones because people are accustomed to them [22] while the widespread of portable devices is enabling students to participate in learning foreign languages at any time and from, any location, whether individually or in contact with others [23]. Smartphones, in particular, are increasingly becoming an ordinary part of our daily lives and their remarkable capacity and applications are extremely varied to be used in language teaching as these applications have opened new windows of opportunity, innovatively shaping the way instructors teach and students learn [24]. In this regard, the big and touch-sensitive screens of today's smartphones offer great advantages in contrast to pre-smartphone mobile devices [25]. Smartphones operating on Android or other applications have become readily available among students, due to the significant reduction in the cost of acquiring a standard smartphone [26]. Furthermore, smartphones can function as miniature classrooms wherein learners can partake in the "anytime, anywhere" learning movement [27].

Nevertheless, Hashemi et al. [12] pointed out to some disadvantages of mobile learning such as the small mobile and PDA screens which limit the amount and type of information that can be displayed, the limited storage capacities for mobiles, and mobile batteries have to be 
charged regularly, Furthermore, it is difficult to use moving graphics especially with mobile phones, and bandwidth may degrade with a larger number of users when using wireless networks. Thus, under the controversial issue of using smartphones in the classroom, the current study aims to investigate the attitudes of EFL teachers towards using smartphones in classroom among Palestinian secondary students during COVID-19 pandemic.

\section{Review of Related Literature}

A great deal of research has been done and published in the field of m-learning and on investigating teachers' and students' attitudes towards using smartphones in education owing to the fact that mobile phones offer unique opportunities for learners of English as a foreign language (EFL) to boost their language skills [29]. In this regard, Alrefaai [29] explored graduate EFL students' attitudes toward the use of mobile phones in language learning among 70 graduate EFL students at King Khalid University in Saudi Arabia. Results revealed that students' attitudes were positive, and there was a significant difference in students' attitudes in favour of female students. Additionally, the results showed that some students use smartphones effectively without facing any problems, whereas the majority of students face various challenges such as technical difficulties, the small size of the screen and distraction.

With regard to mobile learning advantages and the educational value of a specific mobile learning strategy as well as difficulties encountered, Pombo and Marques [30] found that most of the 244 students attending the second and third cycles of basic education had a positive perspective regarding mobile learning and valued the advantages of being easy to find up-to-date information, motivating for learning and easy to carry along while difficulties were related to internet connection, its slowness and prohibition of mobile devices in schools

Walsh [31] who studied the role of smartphones in communication language teaching confirmed the possibility to use phone devices for communicative purposes in the EFL classroom since smartphones provide opportunities to implement the communicative approach successfully and students thought that MALL classes are enjoyable, exciting, and motivating.

Alabsi and Alghamdi [32] found that Saudi university EFL students' opinions and perceptions of the usage and functions of WhatsApp communication were positive as WhatsApp was used a popular communication platform amongst the students, and therefore facilitated language learning in certain aspect like inquiries and announcements. On the other hand, Deng and Kong [33] found that the 79 university students in a comprehensive university in Hong Kong, were active users of mobile phones and heavily engaged with digital devices whereas instant messenger was the most frequently used app on a daily basis and inside the classroom. Even in a different scientific discipline like nursing, mobile technology was used by 586 nursing students from three universities in Ghana for doing homework with gender differences in terms of perceived usefulness of m-learning while age differences existed in terms of ease of use of m-learning in addition to positive attitudes toward the use of m-learning [34].

Furthermore, results of a thematic synthesis methodology used to develop a framework for integrating mobile devices in teaching and learning showed that mobile integration comprises four main parts: beliefs, resources, methods and purpose [35]. Besides, Calabrich [36] who investigated English language learners' perceptions of mobile-assisted language learning revealed that students' perceptions were generally positive while distraction was one of the serious problems students faced when using mobile devices in the language classroom.

In a different context with different cultural values and norms like Saudi Arabia, the five teachers and most of the fifty-two students at Aljouf University thought that mobile phones can accelerate students' English language learning, improve students' pronunciation and communication skills and help them become autonomous learners whereas using a mobile phone for an unlimited number of hours a day may cause health problems and increase the potential for stress [37]. With regard to the effectiveness of mobile applications on teaching, Basal et al.[24] demonstrated the effectiveness of mobile applications on learning idioms beyond the classroom. Such findings are supported by the results of [23] which revealed positive attitudes among teachers and students at the University of Batna towards the effectiveness of MALL while listening, speaking, reading, and culture were the main aspects that can be enhanced. By the same token, the teachers' attitudes towards the use of smartphones for learning were changed after experiencing a mobile game since the game was enjoyable, promoted collaboration and created motivation to win [38]. These attitudes were similar to the attitudes of 300 female EFL college students' toward mobile learning which showed that the majority $(80.3 \%)$ of the students had positive attitudes towards the use of mobile devices in e-learning and teaching [39].

In terms of using mobile devices in distance learning, findings of a study conducted among 269 adult students showed that distance learners were aware of how to use their mobile devices, and their importance in learning the target language especially using them to listen to the target language, to access their courses and to download audio-visual resources [40]. As regards the attitudes of students and teachers towards mobile-assisted language learning (MALL), positive attitudes were revealed which urged students to express their willingness and motivation to use their mobile devices for language learning 
especially listening, speaking, reading, and vocabulary [41]. These attitudes and perceptions are not different from the perceptions of 286 language students at the University of Manchester who indicated that mobile phones were useful in learning writing, speaking, pronunciation, vocabulary, grammar, and assessment in addition to using them for different purposes such as looking up words, phrases, idiomatic expressions; translating words/phrases into their mother tongue and vice versa; listening to how words are pronounced; looking for definitions in the target language; and revising and practicing vocabulary [42]. Similarly, the 37 students who were using smartphones and 'WhatsApp' during 40 days teaching practice schedule indicated favorable attitudes towards m-learning and learning through WhatsApp while married students found learning through WhatsApp disruptive to the extent that they prefer to learn in traditional classroom which does not collide with their family time. The students concluded that mobile devices provide significant opportunities to help learners become more autonomous and also have the potential to change the delivery of teaching and learning [9]. Likewise, the attitudes of six teenagers ( 3 males and 3 females) who used mobile devices toward using mobile devices were positive since they used their mobiles for social networking, gaming, searching for information, and ubiquitous learning [43].

Added to these positive attitudes which seem to emerge from the several applications and functions provided by the mobile phones, [44] indicated statistically significant differences in the performance of the experimental group which learnt vocabulary through mobile phones mobile devices with Android applications such as WhatsApp. These results appear to coincide with Tsinakos [28] who maintained that mobile learning invests in four major attributes: providing easier access to education and information, improving the experience and quality of learning, improving the decision-making skills of individuals and improving the administration, management and governance of local, national and regional education systems. However, findings of a study aimed at examining the effect of using smartphones on the achievement of forty foundation-year students at King Abdul-Aziz University English showed that the impact of using mobile phones was not statistically significant although students had positive attitudes toward using mobile phones in the EFL classroom [45].

Again, with regard to teachers' and students' attitudes around the world towards specific mobile applications, findings from the Iranian context revealed moderately positive attitudes towards the use of electronic dictionaries for learning EFL regardless of some obstacles and challenges, including lack of training on the use of electronic dictionaries, lack of facilities to use electronic dictionaries in EFL classrooms, and distraction from learning caused by using electronic dictionaries in the classroom [46]. The majority of EFL students who used electronic dictionaries installed on their cellphones said that teachers banned them from using mobile devices inside the classroom whereas $31.30 \%$ of participants said that teachers accept the fact of using these devices inside the class. Six out of fourteen teachers responded that they allow the use of mobile devices inside classroom, while the rest eight teachers indicated that they do not allow mobile phone usage inside classroom.

In terms of the limitations of mobile learning, they can be divided into psychological, pedagogical, and technical limitations [12]. Contrary to these limitations, a mobile phone can be used in language learning as a camera to take pictures; a recorder of conversations and language from various sources; a tool for text messaging to reinforce vocabulary learning and writing skills, a means for social networking and blogging; a platform for distributing listening and reading materials ,playing games; checking students' comprehension; as well as researching and data collection [47]. As for exploring the potential of cell phones as tools in EFL teaching, the results obtained from five EFL classrooms and their teachers in Bangladesh showed positive attitudes among teachers and students because cell phone use enhanced motivation and collaboration from both sides [48]. Similarly, finding obtained from a study that aimed to investigate the perceptions of EFL teachers in Bangladesh showed a positive attitude towards using iPods and cell phones as complementary tools to improve students' listening skills [49].

However, regardless of the various favorable functions and features discussed above, most smartphones have some technical factors that might affect their use such as the small size and low resolution of screens in addition, the limited speed of using a mobile device which is one-tenth the speed of using a computer. Accordingly, one solution to the technical limitations of a small screen size and keyboard is the use of tablets instead of mobile phones [25].

The aforementioned review of literature has shown that most teachers and students have positive attitudes towards the use of mobile phones in language learning [29], [30], [31],[32] and [33]. Furthermore, a great deal of research focused the educational benefits of mobile phones in several contexts [23], [41], [42],[43], [44], [28] and [47]. Other researchers, on the other hand, pointed to some problems and disadvantages that might accompany using mobile phones and smartphones [25], [46],[33],[36] and [30], among others. However, with these previous studies and their results and recommendations in mind, the current study is different in its objectives and context since it aims to investigate the attitudes of EFL teachers towards using smartphones in the classroom among Palestinian secondary students during a critical period governed by COVID-19 pandemic. 


\section{Methodology}

\subsection{Statement of the Problem}

Around three months ago, someone posted on a Facebook page a photo of a school kid who was laughing besides a statement that says," They said no phone inside the school! Today school is inside the phone". This post has sparked the researchers' curiosity to shed some light on the issue of using smartphones in today's educational process. Despite the various benefits of smartphones in today's life and the rapid increase in the number of people who own mobile phones and smartphones in Palestine according to the latest statistics, using smartphones in the Palestinian schools constitutes a controversial issue among teachers and decision-makers. This might be due to the claim that the increasing spread of smartphones does not necessarily lead to employing them in education and that learners usually own their smartphones when they are older, missing the opportunity to benefit from them in younger age [28]. Added to this, students at all stages in Palestine are not allowed to bring their mobile phones to school under any conditions since the regulations of the Ministry of Education ban using smartphones inside the school to the extent that principals and teachers used to collect students' mobile phones during the school day and return them by the end of the school day. This banning might be due to the fact that government decision-makers and even teachers are unaware of the significant role of smartphone technology in learning English in Palestine. Some people, moreover, think that smartphones might be time-wasting and tend to cause some kind of chaos, distraction (resulted from watching videos, playing online games, and using social networks for purposes unrelated to language learning) or lack of discipline or even some health problems, technical problems such as network failures, and difficulties in downloading certain files, to name few. Hence, the current study aims at investigating the attitudes of EFL teachers towards using smartphones in the classroom among Palestinian secondary students during the COVID-19 pandemic.

\subsection{Significance of the Study}

To the researchers' best knowledge, no previous studies in Palestine investigated the teachers' attitudes towards using smartphones in the classroom during coronavirus pandemic. Thus, results of this study could guide teachers, educators and educational leaders in Palestine to discuss the issue of smartphone integration into EFL learning so as to enhance students' achievement and help them to cope with the ongoing conditions. The possible advantages and applications of today's smartphones should not be underestimated especially when students have their own smartphones anywhere anytime. The researchers of this study argue that exploring the EFL teachers' attitudes towards using smartphones among secondary students in the Palestinian context might bring about positive changes in the EFL learning approaches through using the various applications and features of these smartphones. Thus, the results of this study are hoped to encourage the decision- makers in the Palestinian Ministry of Education to develop new policies and procedures that take into consideration the effects and benefits of mobile technology and how these can positively affect the educational process especially under the ongoing spread of COVID-19 which forced all countries to convert to e-learning and distance learning. Furthermore, the results of this study are hoped to encourage other researchers to investigate the attitudes of the students towards using smartphones in learning EFL inside the classroom. The results are also hoped to encourage EFL teachers to try some possible uses of smartphones in EFL learning inside the classroom especially with the availability of internet access in most schools in Palestine. Lastly, the results are hoped to motivate curriculum designers in Palestine to include special activities and exercises that necessitate the use of smartphones when learning English either inside the school or outside.

\subsection{Question of the Study}

The main question underlying this study is: what are the attitudes of EFL teachers towards using smartphones in the classroom?

\subsection{Hypotheses of the Study}

1. There are no statistically significant differences at $\alpha \leq$ 0.05 in the attitudes EFL teachers towards using smartphones in the classroom due to gender.

2. There are no statistically significant differences at $\alpha \leq$ 0.05 in the attitudes EFL teachers towards using smartphones in the classroom due to years of teaching experience.

3. There are no statistically significant differences at $\alpha \leq$ 0.05 in the attitudes EFL teachers towards using smartphones in the classroom due to the grades the teacher teaches.

4. There are no statistically significant differences at $\alpha \leq$ 0.05 in the attitudes EFL teachers towards using smartphones in the classroom due to teacher's qualification.

\subsection{Participants}

The participants of the study consisted of fifty-eight EFL teachers (36 females and 22 males) who teach the secondary stage in the academic year 2020/2021. Their background ranged from novice to experienced teachers with variation in terms of qualification, gender, and grades as shown in Table (1) below. 
Table 1. Distribution of Sample Study Independent Variables

\begin{tabular}{|c|c|c|c|}
\hline Variable & Class & Frequency & Percentage \\
\hline \multirow{3}{*}{ Gender } & Male & 22 & 37.9 \\
\cline { 2 - 4 } & Female & 36 & 62.1 \\
\hline \multirow{3}{*}{ Experience } & Diploma & 1 & 1.7 \\
\cline { 2 - 4 } & B.A & 46 & 79.3 \\
\cline { 2 - 4 } & M.A & 11 & 19.0 \\
\cline { 2 - 4 } & Between 5 and 10 & 11 & 19.0 \\
\cline { 2 - 4 } & 10 or over & 36 & 62.1 \\
\hline \multirow{3}{*}{ Grades } & $\begin{array}{c}\text { Primary and } \\
\text { Medium } 5^{\text {th }}-10^{\text {th }} \\
\text { grade }\end{array}$ & 36 & 62.1 \\
\cline { 2 - 4 } & $\begin{array}{c}\text { Secondary" } 10^{\text {th }} \\
-12^{\text {th }}\end{array}$ & 22 & 37.9 \\
\hline Total & & 58 & $100 \%$ \\
\hline
\end{tabular}

\subsection{Data Collection and Instruments}

The descriptive analytical method design was used to collect both quantitative and qualitative data using an electronic questionnaire and a focus group using Zoom. The questionnaire which was circulated via email to the 58 EFL teachers consisted of two sections, the first involved personal information related to specific variables such as gender, years of experience, the grades the teacher teaches and teacher's qualification while the second comprised 30 five-point scale items in which Strongly Agree $=5$ points, Agree $=4$ points, Undecided $=3$, Disagree $=2$ points and Strongly Disagree $=1$ point.

To ensure the content and construct validity of the questionnaire, it was reviewed by a panel of five professors in the field of TEFL at the Faculties of Educational Sciences at Al-Quds Open University and An-Najah National University in addition to two English Language supervisors working for the Ministry of Education. The questionnaire, then, was piloted on 10 teachers with similar level of proficiency to determine whether the questions were comprehensible and can be interpreted by the teachers without any difficulty. The respondents' feedback and the jury suggestions were taken into consideration to modify and improve the questionnaire content and wordings by omitting, adding or rephrasing items bringing the number of items from 42 to 30. Based on these modifications, the content validity was approved. On the other hand, the reliability of the questionnaire as calculated through Cronbach Alpha formula was (0.93).

Furthermore, the qualitative data were collected through a focus group meeting organized by the two researchers using a video conferencing software application called Zoom. The meeting comprised six EFL teachers (3 males and 3 females) from the study sample and lasted for 90 minutes. This focus group meeting focused on four main questions: (1) What do you think of using smartphones for learning purposes inside classroom? (2) What are the possible advantages of using smartphones inside the EFL classroom? (3) Are you with or against using smartphones in the classroom by your students? Why? (4) Do you think that using smartphones in the classroom by your students involve some obstacles or challenges?

\subsection{Data Analysis}

The Statistical Package for Social Sciences (SPSS) was used to analyze the quantitative data through utilizing frequencies, means, and standard deviations. Moreover, t-test for Independent Samples and One-Way Analysis of Variance were used to find out descriptive statistical analysis. To analyze the findings, the researchers used the following scale to represent the estimation level of teachers' responses.

\begin{tabular}{|l|l|}
\hline 4.5 and more Very High $\quad 4-4.49$ High $\quad 3.50-3.99$ Moderate \\
\hline 3- 3.49 Low less than 3 Very Low \\
\hline
\end{tabular}

On the other hand, the qualitative data were analyzed following the five-phased qualitative analysis method [50]. Following this method, the two researchers and the two teachers individually watched the recording of the focus group meeting twice and worked on the analysis using the four qualitative questions as a base. The collected answers were grouped in closed-related clusters. After that, the data were recombined into broader categories to be interpreted and find out the interrelationships between them, and finally stating the conclusions.

\section{Results}

\subsection{Result of the Main Question}

One main question guided the current study that aimed at investigating the attitudes of EFL teachers towards using smartphones in the classroom among Palestinian secondary students in addition to identifying the effect of gender, qualification, experience and the grades that the teacher teaches. To answer the question "What are the attitudes of EFL teachers towards using smartphones in the classroom?", means and standard deviations were used as shown in Table (2). 
Table 2. Means and Standard Deviations of the attitudes of EFL teachers towards using smartphones in the classroom

\begin{tabular}{|c|c|c|c|c|}
\hline No. & Item & Means & $\begin{array}{c}\text { standard } \\
\text { deviations }\end{array}$ & $\begin{array}{c}\text { Estimation } \\
\text { level }\end{array}$ \\
\hline 1. & Smartphones help students become active learners. & 3.34 & .94 & Low \\
\hline 2. & Smartphones empower student-centered approaches. & 3.39 & .89 & Low \\
\hline 3. & $\begin{array}{l}\begin{array}{l}\text { Smartphones allow students to access learning resources including online } \\
\text { dictionaries. }\end{array} \\
\end{array}$ & 3.82 & .79 & Moderate \\
\hline 4. & Smartphones enable students to access educational blogs and forums. & 3.81 & .66 & Moderate \\
\hline 5. & $\begin{array}{l}\text { Smartphones enable students to take pictures and videos for educational } \\
\text { learning purposes. }\end{array}$ & 4.00 & .70 & High \\
\hline 6. & $\begin{array}{l}\text { Smartphones allow students to exchange text messages with classmates for } \\
\text { educational purposes. }\end{array}$ & 3.93 & .72 & Moderate \\
\hline 7. & Smartphones enable students to download educational materials easily. & 4.03 & .62 & High \\
\hline 8. & Using a smartphone helps students to learn in a way that suits their abilities. & 3.44 & .97 & Low \\
\hline 9. & Smartphones help students record audio and video lessons. & 4.05 & .66 & High \\
\hline 10. & Smartphones enable students to accomplish learning tasks quickly. & 3.53 & .84 & Moderate \\
\hline 11. & $\begin{array}{l}\text { Smartphones provide a means of accessing materials and knowledge inside } \\
\text { the classroom. }\end{array}$ & 3.63 & .83 & Moderate \\
\hline 12. & Using smartphones decreases the degree of boredom in the classroom. & 3.48 & 1.03 & Low \\
\hline 13. & $\begin{array}{l}\text { Using smartphones creates an enjoyable learning environment in the } \\
\text { classroom. }\end{array}$ & 3.68 & .94 & Moderate \\
\hline 14. & Smartphones provide a variety of learning experience in the classroom. & 3.70 & .79 & Moderate \\
\hline 15. & $\begin{array}{c}\text { Smartphones help students communicate with both the teacher and } \\
\text { classmates. }\end{array}$ & 3.86 & .68 & Moderate \\
\hline 16. & $\begin{array}{l}\text { Through smartphones, students can receive immediate feedback about their } \\
\text { performance. }\end{array}$ & 3.75 & .80 & Moderate \\
\hline 17. & $\begin{array}{c}\text { Smartphones help students share information and ideas through social } \\
\text { network environment: Facebook, WhatsApp, Messenger...etc. }\end{array}$ & 4.03 & .64 & High \\
\hline 18. & $\begin{array}{l}\text { Using smartphones enables students to access information anytime, } \\
\text { anywhere. }\end{array}$ & 3.98 & .73 & Moderate \\
\hline 19. & $\begin{array}{l}\text { Using smartphones enables students to manage learning according to their } \\
\text { needs. }\end{array}$ & 3.58 & .87 & Moderate \\
\hline 20. & $\begin{array}{l}\text { Using smartphones increases students' motivation to learn English in } \\
\text { different ways. }\end{array}$ & 3.74 & .80 & Moderate \\
\hline 21. & $\begin{array}{l}\text { The use of smartphones promotes interaction between the teacher and the } \\
\text { students. }\end{array}$ & 3.65 & .90 & Moderate \\
\hline 22. & $\begin{array}{l}\text { The use of smartphones increases interaction between the students inside the } \\
\text { classroom. }\end{array}$ & 3.56 & .86 & Moderate \\
\hline 23. & Smartphone learning is more attractive than the traditional ways. & 3.31 & 1.09 & Low \\
\hline 24. & $\begin{array}{l}\text { Smartphones enable students to collaborate with the teacher and peers in the } \\
\text { classroom. }\end{array}$ & 3.58 & .93 & Moderate \\
\hline 25. & Using smartphones enhances students' pronunciation and speaking skills. & 3.68 & .90 & Moderate \\
\hline 26. & $\begin{array}{c}\text { Smartphones enable students to listen to English native speakers talking } \\
\text { about various topics, }\end{array}$ & 4.03 & .62 & High \\
\hline 27. & $\begin{array}{l}\text { Using smartphones helps students access YouTube, and online dictionaries to } \\
\text { enhance learning. }\end{array}$ & 4.12 & .69 & High \\
\hline 28. & $\begin{array}{l}\text { Using smartphones involves communication failure due to poor network } \\
\text { connectivity. }\end{array}$ & 4.10 & .70 & High \\
\hline 29. & $\begin{array}{c}\text { Using smartphones leads to some distraction when using them for language } \\
\text { learning. }\end{array}$ & 3.70 & .72 & Moderate \\
\hline 30. & Using smartphones leads to disciplinary problems. & 3.67 & .75 & Moderate \\
\hline \multicolumn{2}{|r|}{ Total Degree } & 3.74 & .45 & High \\
\hline
\end{tabular}


Table (2) shows that the total degree of teachers' attitudes towards using smartphones in the classroom was (3.74) which suggests a moderate level. The highest means was given to the item "Using smartphones helps students access YouTube, and online dictionaries to enhance learning" which scored (4.12) and to the item "Using smartphones involves communication failure due to poor network connectivity" which scored (4.10). On the other hand, the item "Smartphone learning is more attractive than the traditional ways" scored the lowest mean (3.31).

\subsection{Results of the Hypotheses}

H1. There are no statistically significant differences at $\alpha$ $\leq 0.05$ in the attitudes EFL teachers towards using smartphones in the classroom due to gender. To test the first hypothesis, t-test for Independent Samples was used and Table (3) shows the results.

Table 3. T-test for Independent Samples of the attitudes EFL teachers towards using smartphones in the classroom due to gender

\begin{tabular}{|c|c|c|c|c|c|c|}
\hline Domain & Gender & $\mathrm{N}$ & Mean & S. D & $\mathrm{t}$ & Sig.* \\
\hline \multirow{2}{*}{ Total } & Male & 22 & 3.7939 & .53636 & \multirow{2}{*}{.648} & 0.520 \\
\cline { 2 - 5 } & $\begin{array}{c}\text { Femal } \\
\mathbf{e}\end{array}$ & 36 & 3.7130 & .41106 & .648 & \\
\hline
\end{tabular}

*The mean difference is significant at the 0.05 level.

Table (3) shows no statistically significant differences at $(\alpha \leq 0.05)$ on the total degree of the attitudes of EFL teachers towards using smartphones in the classroom due to gender as the significant value was $(0.520)$ which is more than 0.05 .

H2. There are no statistically significant differences at $\alpha$ $\leq 0.05$ in the attitudes EFL teachers towards using smartphones in the classroom due to years of teaching experience. To test the second hypothesis, One Way ANOVA was used, and Tables $(4,5)$ show the results.

Table (5) shows no statistically significant differences at $(\alpha \leq 0.05)$ on the total degree of the attitudes of EFL teachers towards using smartphones in the classroom due to years of teaching experience as the significant value was $(0.881)$ which is more than 0.05 .

Table 4. Frequencies, Means and Standards Deviations of in the attitudes of EFL teachers towards using smartphones in the classroom due to years of teaching experience

\begin{tabular}{|c|c|c|c|c|}
\hline Domain & Experience & $\mathrm{N}$ & Mean & S. D \\
\hline \multirow{4}{*}{ Total } & Less than 5 & 11 & 3.6909 & .40444 \\
\cline { 2 - 5 } & Between 5 and 10 & 11 & 3.7909 & .51318 \\
\cline { 2 - 5 } & 10 or More & 36 & 3.7454 & .46966 \\
\cline { 2 - 5 } & Total & 58 & 3.7437 & .45969 \\
\hline
\end{tabular}

Table 5. Results of One Way ANOVA for the attitudes EFL teacher towards using smartphones in the classroom due to years of teaching experience

\begin{tabular}{|c|c|c|c|c|c|c|}
\hline \multirow{7}{*}{ Domain } & $\begin{array}{c}\text { Source of } \\
\text { variance }\end{array}$ & $\begin{array}{c}\text { Sum of } \\
\text { Squares }\end{array}$ & df & $\begin{array}{c}\text { Mean } \\
\text { Square }\end{array}$ & F & Sig. \\
\hline \multirow{7}{*}{ Total } & $\begin{array}{c}\text { Between } \\
\text { Groups }\end{array}$ & .055 & 2 & .028 & & \\
\cline { 2 - 5 } & $\begin{array}{c}\text { Within } \\
\text { Groups }\end{array}$ & 11.990 & 55 & \multirow{2}{*}{.218} & .127 & .881 \\
\cline { 2 - 5 } & Total & 12.045 & 57 & & \\
\hline
\end{tabular}

* The mean difference is significant at the 0.05 level.

H3. There are no statistically significant differences at $\alpha$ $\leq 0.05$ in the attitudes EFL teachers towards using smartphones in the classroom due to the grades the teacher teaches. To test the third hypothesis, $\mathrm{t}$ - Test for Independent Samples was used and Table (6) shows the results.

Table (6) shows no statistically significant differences at $(\alpha \leq 0.05)$ on the total degree of the attitudes of EFL teachers towards using smartphones in the classroom due to grades the teacher teaches as the significant value was (0.617) which is more than 0.05 .

H4. There are no statistically significant differences at $\alpha$ $\leq 0.05$ in the attitudes EFL teachers towards using smartphones in the classroom due to years of teacher's qualification. To test the forth hypothesis, One Way ANOVA was used, and Tables (7 and 8 ) show the results.

Table 6. T-test for Independent Samples of the attitudes EFL teachers towards using smartphones in the classroom due to grades the teacher teaches

\begin{tabular}{|c|c|c|c|c|c|c|}
\hline Domain & grades & $\mathrm{N}$ & Mean & S. D & t & Sig.* \\
\cline { 1 - 4 } Total & Primary and Medium" 5th -10 th grade & 36 & 3.7676 & .47971 & \multirow{2}{*}{.503} & \multirow{2}{*}{0.617} \\
\hline & Secondary"10th -12th & 22 & 3.7045 & .43294 & & \\
\hline
\end{tabular}

*The mean difference is significant at the 0.05 level.

Table 7. Frequencies, Means and Standards Deviations of in the attitudes EFL teachers towards using smartphones in the classroom due to years teacher's qualification

\begin{tabular}{|c|c|c|c|c|}
\hline Domain & Qualification & N & Mean & S.D \\
\hline \multirow{4}{*}{ Total } & Diploma & 1 & 3.1333 &. \\
\cline { 2 - 5 } & B.A & 46 & 3.7341 & .42429 \\
\cline { 2 - 5 } & M.A & 11 & 3.8394 & .58875 \\
\cline { 2 - 5 } & Total & 58 & 3.7437 & .45969 \\
\hline
\end{tabular}


Table 8. Results of One-Way ANOVA for the attitudes EFL teachers towards using smartphones in the classroom due to years of teacher's qualification

\begin{tabular}{|c|c|c|c|c|c|c|}
\hline \multirow{3}{*}{ Domain } & Source of variance & Sum of Squares & $\mathrm{df}$ & Mean Square & F & Sig. \\
\hline \multirow{3}{*}{ Total } & Between Groups & .478 & 2 & .239 & \multirow{2}{*}{1.135} & .329 \\
\cline { 2 - 5 } & Within Groups & 11.567 & 55 & .210 & & \\
\cline { 2 - 5 } & Total & 12.045 & 57 & & \\
\hline
\end{tabular}

* The mean difference is significant at the 0.05 level.

Table (8) shows no statistical significant differences at $(\alpha \leq 0.05)$ on the total degree of the attitudes of EFL teachers towards using smartphones in the classroom due to teacher's qualification as the significant value was $(0.329)$ which is more than 0.05 .

\subsection{Results of the Qualitative Data Analysis}

As mentioned above, a focus group meeting was conducted using Zoom video conferencing to get in-depth insights into EFL teachers' attitude towards using smartphones in the classroom among Palestinian secondary students during COVID-19 pandemic. Since the meeting was recorded, the two researchers with the help of one teacher worked independently to examine the content of the focus group for the purpose of identifying the themes relevant to the study main question. This type of multiple analysis aimed to ensure some sort of reliability with regard to the major themes discussed throughout the meeting. The focus group meeting focused on four main questions: (1) What do you think of using smartphones for learning purposes inside classroom? (2) What are the possible advantages of using smartphones inside the EFL classroom? (3) Are you with or against using smartphones in the classroom by your students? Why? (4) Do you think that using smartphones in the classroom by your students involve some obstacles or challenges?

Accordingly, these questions which guided the focus group discussion and the answers of the six teachers were classified and tabulated into categories for the sake of analysis and interpretation. Using the thematic units system which includes more global interpretative or explanatory sets of statements [51], five recurrent themes (RT) emerged:

RT1: The six teachers indicated that smartphones can be used in the classroom for educational purposes and only under complete control and supervision of the teacher who should inform the students about the best practices of using the smartphones and to arouse student's awareness of how to use them as educational aids. All teachers pointed to the promising future of smartphones especially in the field of English language learning.

RT2: The participating teachers asserted that the new generations of smartphones are provided with many features and applications that can be used for English language learning in general and English language skills in particular. They gave some examples including listening for comprehension, practicing structure, watching videos relevant to their lessons, creating their own educational videos on the fly, using the smartphone as a dictionary to check the spelling, pronunciation and meaning of new words, introducing the target culture to the students and the various English accents, and using gaming apps, to name few. Three teachers indicated that they use their own smartphone applications like zoom, WhatsApp, Facebook, YouTube and Teams to teach EFL as a means to communicate with students outside the school.

RT3: The teachers also mentioned various benefits of using smartphones in the light of their own experience. These benefits include the smartphone potential to break the regular teaching routine which might include some kind of boredom in addition to smartphones' capacity to provide fun and interactivity based on the various features and applications of new versions which can be carried anywhere and anytime by students. Accordingly, the learning process can take place anywhere not just in schools which enable students to communicate with each other and with their te achers. Such benefits and others seem to enhance collaborative and cooperative learning.

One teacher indicated that as students use their smartphones for a long time during the day, so it's a way to reconstruct their way of thinking and behaviors. Another teacher stressed the privilege of smartphones to make the teaching and learning process pretty quick, smooth, interesting and interdisciplinary which empower students' high order thinking skills.

RT4: Five teachers indicated that they are in favor of using the smartphones in their own classrooms since the teachers and the students are living in the age of high-tech of smartphones but not for a long time. One male teacher assured that he is partly with using smartphones under the teacher's control because students might waste their time and the teacher's time if they are allowed to use their smartphones freely. Three teachers pinpointed the problem of overcrowded classes in the Palestinian public schools which make discipline and control difficult.

RT5: The content analysis of the focus group meeting revealed some problems and challenges related to the issue of using smartphones in the classroom. One teacher pointed to the negative use of internet inside classrooms in addition to misbehaviors from some students who may cause insult or a kind of bullying when students take photos of the teacher and the classmate and post them to the social media. A second teacher confirmed that using smartphones in the classroom is expected to cause 
distraction, chaos and noise especially when smartphones ring or vibrate. A third teacher maintained that smartphones might be used for cheating when students can exchange answers between them using either the Bluetooth function or via internet applications. Moreover, one teacher talked about the internet safety problem which necessitates complete control from the teacher and this is not an easy task in addition to the frequent problem of bad internet connection. Another male teacher summed up his point of view by highlighting some technical, financial, and moral issues and he gave examples of the slow internet connection or even the unaffordability of internet fees plus lack of experience and motivation among old teachers. A female teacher expressed somehow a negative attitude when she stated that using smartphones can be useless in some cases. For instance, weak students who have no motivation are rarely involved in addition to the misuse of smartphones.

\section{Discussion}

The results of this study indicated that the attitudes of EFL teachers towards using smartphones in the classroom by secondary students were not high but moderately positive. This result might be due to the fact that the teachers have their own fears and worries regarding the use of the smartphones in the classroom by secondary students which was pinpointed in the focus group meeting when some teachers talked about several problems and challenges including the undesired use of internet inside classrooms, some expected misbehavior's of students, the possibility of distraction and noise caused by smartphones ringtone or vibration, using smartphones for cheating, or prohibition of mobile devices in schools as found by Pombo and Marques [30]. This interpretation is supported by the findings of other researchers who found some challenges and difficulties that might emerge when using mobile phones in the classroom including the disruption and distraction caused by these devices and misusing them in the classroom [25],[46],[33],[36] and [30].However, the above result appears to be in consistent of previous research that indicated either high or moderate positive attitudes towards using mobile phones and smartphones in EFL learning [29],[34],[36] and [37]. This result is also supported by the teachers' responses in the focus group who asserted that smartphones are provided with several features and applications that make them useful for EFL learning.

The results of the current study also showed no statistically significant differences at $(\alpha \leq 0.05)$ on the total degree of the attitudes of EFL teachers towards using smartphones in the classroom due to gender. This result might be due to the fact that both female and male teachers mostly work under the same conditions and the same regulations that prohibit the use of smartphones inside the classroom regardless of their great benefits expressed by them in the focus group. This result seems to disagree with [29] and [43] who found significant differences in attitudes in favour of female students who used their mobiles more than males for learning.

More importantly, the results of this study found no statistically significant differences at $(\alpha \leq 0.05)$ on the total degree of the attitudes of EFL teachers towards using smartphones in the classroom due to teachers' years of experience, qualifications and the grades they teach. Such results demonstrate a kind of consensus between the participants which undermines the influence of the aforementioned variables in favor of the various benefits of using smartphone technology either inside the classroom or outside. This means that whether the teachers teach primary, medium or secondary grades, whether they have long experience or short experience and whether they have diploma or more, they tend to reveal nearly the same moderate positive attitudes towards smartphone technology and its promising future in EFL learning context. Such claim is supported by the teachers' opinions in the focus group meeting when they maintained that smartphones make the teaching and learning process pretty quick, smooth, interesting and interdisciplinary which empower students' high order thinking skills. However, these attitudes might contradict some people who tend to think that novice young teachers who enter the teaching profession are expected to feel more comfortable when employing the smartphones and other new high-tech advancements since they have grown with these new types of technology available for everyone at the push of a button. The various benefits mentioned by the teachers seem to motivate teachers to be in favour of using smartphone technology in EFL classroom since previous research showed positive attitudes among students towards smartphone technology as revealed throughout the previous literature review.

Regarding the results of the content analysis of the focus group meeting, teachers pointed to some problems and challenges that might accompany the use of the smartphones in the classroom environment such as the negative misuse or misbehavior's from some students creating distraction, chaos and noise, the students' tendency to use smartphones for cheating, the slow internet connection or even the unaffordability of internet fees. These issues agree with some previous research conducted by [25], [46], [33], [36] and [30].

\section{Conclusions and Implications}

The results of both quantitative and qualitative data analysis in this study indicated positive attitudes, although moderates with some reservations, towards using the smartphone technology by the secondary students in inside the classroom. Such attitudes possibly might be due 
to the various features and applications provided to the new generations of smartphones available in the hands of the students' day and night. These positive attitudes pave the way for new educational interventions in the field of EFL learning in the Palestinian context which should be initiated by the new generations of teachers who dream to enrich their classroom practices for the benefits of new generations of students who, to say the least, are addicted to their smartphones and to the internet applications as well. Thus, it is time to rethink methods of teaching and learning in the 21 st century through investing in any available means of communication so as to avoid being left behind. Added to the various features and applications available on the smartphones, owning a smartphone is becoming affordable in Palestine as well as the intent services as indicated by the latest statistics which should encourage policymakers to take some revolutionary decisions and initiatives in favor of using the smartphone technology in the classroom by secondary students especially these days when the continuing spread of COVID-19 threatens all educational systems all over the world.

In summary, the results of this study contribute to the body of literature in three significant ways: (1) The results confirmed the findings obtained from previous studies that demonstrated the positive attitudes of EFL teachers and other educators towards the use of smartphone technology inside the classroom and outside. (2) The study might be the first one conducted in the Palestinian educational context during the corona virus pandemic in the area of using smartphone technology in EFL learning. (3) The literature review in this study is expected to provide both teachers and students with a great deal of ideas on how to use smartphone features and applications for educational purposes.

\section{Limitations and Suggestions for Future Research}

The characteristics and the number of the participants in this study may limit the generalization of the results. In addition, this study was conducted during the Coronavirus pandemic when all teachers were overloaded and were facing financial pressures in Palestine. These conditions might have left certain impact on teachers' attitudes and their beliefs. Nevertheless, the results obtained from the questionnaire and the focus group shed some light on the readiness of EFL teachers to update their methods of teaching and to cope with the ongoing challenges imposed by Coronavirus pandemic.

Therefore, for future research work, it seems impressive to investigate students' attitudes towards using smartphone technology in the classroom and identifying the possible challenges and problems they might face regarding this use. Further research is needed to explore new functions and applications available on the latest generations of smartphones which are getting much smarter day after day. For example, thanks to recent technological advancements, it is possible nowadays to make the smartphone screen much clearer and bigger through using Mobile Phone 3D Magnifier Projector Screen, using long-battery life smartphones that could be charged $100 \%$ in less than a minute, using virtual reality applications, incorporating graphene into smartphones could allow for designs to be ultra-thin, transparent, flexible and virtually indestructible, and so forth. These futuristic features are expected to revolutionize the way we use our smartphones for educational purposes and they might encourage other researchers to explore how students use their smartphones for educational purposes in general, and for EFL learning in particular.

Finally, the door is left open for other researchers and practioners to carry out experimental or quasi-experimental studies where schools students in Palestine are allowed to use their smartphones to learn specific skills or carry out specific tasks in the classroom setting to find out the possible impact of using smartphones. Such studies might lead to some impressive changes in the methods of teaching and learning English in the Palestinian context.

\section{Acknowledgment}

The research was supported by Canterbury Christ Church University through its QR Global Challenges Research Fund (GCRF) allocation. GCRF is part of the UK's Official Development Assistance (ODA) commitment.

\section{REFERENCES}

[1] Zehr, M.A, "Teaching the teachers," Education Week: Technology Counts, vol. 17, no.11, pp.26-29,1997. https://www.edweek.org/media/ew/tc/archives/TC97full.pd f.

[2] Jose. J. and Zainol Abidin, M. J., "Application of Information and Communication Technology Tools for English Language Teaching in an Omani Context", Arab World English Journal (AWEJ) Special Issue on CALL, No.2 July, pp.51-67, 2015 https://www.academia.edu/1660 7233/Arab_World_English_Journal_AWEJ_Special_Issue on_CALL_No_2_July_2015.

[3] Gitsaki, C and Robby, A.R,. "Evaluating the use of mobile technology in math education", in Mobile Learning and STEM, $1^{\text {st }}$ ed, Routledge, Taylor \& Francis, 2016., pp.187-198.

[4] Meyer, B. "Mobile Devices and Spatial Enactments of Learning: iPads in Lower Secondary Schools", $12^{\text {th }}$ International Conference on Mobile Learning,. Vilamoura, 
Algarve, Portugal, April 9-11, 2016. https://mlearning-conf .org/wp-content/uploads/2016/04/ML2016.pdf.

[5] Cook, J., Pachler, N. \& Bachmair, B. "Ubiquitous mobility with mobile phones: A cultural ecology for mobile learning", E-Learning and Digital Media, vol.8, no.3, 181-195, 2011 https://journals.sagepub.com/doi/10.2304/elea.2011.8.3.181

[6] Richardson, I. and Wilken, R. "Parerga of the third screen: Mobile media, place, presence", in Mobile technology and place. Routledge, 2012., pp. 181-197.

[7] National Center for Educational Statistics, U.S. Department of Education," Teachers' tools for the 21st Century. A report on teachers' use of technology (2000).. https://nces.ed.gov/ pubs2000/2000062.pdf.

[8] Sierschynski, J.," Integrating two technologies: Tablets and teaching", in in Mobile Learning and STEM, 1st ed, Routledge, Taylor \& Francis, 2016., pp.187-198..

[9] Bansal, T. \& Joshi , D., “A Study of Students' Experiences of Mobile Learning", Global Journal of HUMAN-SOCIAL SCIENCE: H Interdisciplinary, vol. 14, no. 4, 2014. https://globaljournals.org/GJHSS_Volume14/3-A-Study-ofStudents-Experiences.pdf.

[10] Dettori, G \&Lupi, V., "ICT and new methodologies in language learning", Procedia- Social and Behavioral Sciences vol 2, no 2 pp.. 2712-2716, 2010. DOI: 10.1016/j.sbspro.2010.03.401.

[11] Geddes, S.J, "Mobile learning in the 21st century: benefit for learners", Knowledge Tree: An E-journal of Flexible Learning in VET,vol 6,2004. http://hdl.voced.edu.au/10707/383787.

[12] Hashemi, M; Azizinezhad, M.; Najafia, V ; Nesari., A. J, "What is Mobile Learning ? Challenges and Capabilities" Procedia - Social and Behavioral Sciences vol.30. pp. 2477 2481,2011. https://doi.org/10.1016/j.sbspro.2011.10.483.

[13] Schroeder, B. "Mobile and Digital: Perspectives on Teaching and Learning in a Networked World". In Global Mobile Learning Implementations and Trends, China Central Radio \& TV University Press.2013. pp.105-118.

[14] Andujar, A," Benefits of mobile instant messaging to develop ESL writing" System, vol. 62, pp.63-76, ,2016, https://www.sciencedirect.com/journal/system/vol/62/suppl /C.

[15] Marzouki, O. F., Idrissi, M. K., \& Bennani, S, "Mobile Education-proposing a Mobile Learning Model for Designing an Institutional Mobile Scenario", Research Journal of Applied Sciences, Engineering and Technology, vol. 7, no.21, pp. 4584-4592, 2014. https://maxwellsci.com/ jp/mspabstract.php?doi=rjaset.7.837.

[16] Sung, Y., Chang, K. \& Yang, J, "How effective are mobile devices for language learning? A metaanalysis". Educational Research Review, vol. 16, pp. 68-84, 2015.https://doi.org/1 0.1016/j.edurev.2015.09.001.

[17] El Hariry, N. A, "Mobile phones as useful language learning tools" European Scientific Journal, vol. 11, no.16, pp. 298-317. 2015.http://eujournal.org/index.php/esj/article/vie $\mathrm{w} / 5870$.

[18] Traxler, J., "Mobile Learning in International Development" in Global Mobile Learning Implementations and Trends, In
Global Mobile Learning Implementations and Trends, China Central Radio \& TV University Press.2013, pp.45-60.

[19] PCBS (Palestinian Central Bureau of Statistics), 2019. http://www.pcbs.gov.ps/Portals/ Rainbow/Documents/ICT 2014_\%2001E.htm.

[20] PCBS (Palestinian Central Bureau of Statistics),2020. http://pcbs.gov.ps/site/512/default.aspx?lang=en\&ItemID=3 774.

[21] Pew Research Center, "Internet \& Technology Statistics", 2020.https://www.pewresearch.org/internet/fact-sheet/mobi $1 \mathrm{e} /$.

[22] Cui, G., Wang, A, “Adopting Cell Phones in EFL Teaching and Learning", Journal of Educational Technology Development and Exchange, vol.1, no.1, 2008. https://aquila.usm.edu/jetde/vol1/iss1/6/.

[23] Saidouni, Kh. and Bahloul, A., "Teachers and Students' Attitudes towards Using Mobile-Assisted Language Learning in Higher Education", Arab World English Journal (AWEJ), no.3, pp. 123-140, 2016. https://docplayer.net/923 61439-Arab-world-english-journal.html.

[24] Basal, A; Yilmaz, S; Tanriverdi , A \& Sari., L, "Effectiveness of Mobile Applications in Vocabulary Teaching", Contemporary Educational Technology, vol.7, no.1, pp. 47-59, 2016. https://doi.org/10.30935/cedtech/616 2 .

[25] Stockwell, G, "Using mobile phones for vocabulary activities: Examining the effect of the platform", Language Learning \& Technology, vol.14, no.2, pp. 95-110, 2010. https://www.lltjournal.org/item/2690.

[26] Plana, M. G. C., Escofet, M. I. G., Figueras, I. T., Gimeno, A., Appel, C., \& Hopkins, J, 'Improving learners' reading skills through instant short messages: A sample study using WhatsApp", $4^{\text {th }}$ World-CALL Conference, Glasgow, 10-13 July, 2013. https://www.researchgate.net/publication/25571 8202_Improving_learners'_reading_skills_through_instant short_messages_a_sample_study_using_WhatsApp/citation /download.

[27] Schachter, R, "Mobile devices in the classroom", District Administration, vol. 45, no. 10, pp.31-34, 36, 2009 https://eric.ed.gov/?id=EJ866588.

[28] Tsinakos . A, "State of Mobile Learning Around the World", in Global Mobile Learning Implementations and Trends, China Central Radio \& TV University Press, 2013, pp.4-44.

[29] Alrefaai, I, "Exploring EFL Graduate Students' Attitudes toward, and Use of Mobile Phones in Language Learning", Arab World English Journal, Special Issue: The Dynamics of EFL in Saudi Arabia, pp.70-84, 2019. DOI: https://dx.doi.org/10.24093/awej/efl1.6.

[30] Pombo, L. and Marques, M, "Improving students' learning with a mobile augmented reality approach - the EduPARK game", Interactive Technology and Smart Education, vol. 16 No. 4, pp. 392-406, 2019. https://doi.org/10.1108/ITSE-062019-0032.

[31] Walsh, R, "Smartphones and CLT: Threat or opportunity?" Teaching English with Technology, vol.19, no.2, pp. 59-69, 2019. http://www.tewtjournal.org.

[32] Alabsi, K. M., \& Alghamdi, F.M.A, 'Students' Opinions on 
the Functions and Usefulness of Communication on WhatsApp in the EFL Higher Education Context", Arab World English Journal, Special Issue 1: Application of Global ELT Practices in Saudi Arabia. pp. 129- 144, 2019. DOI: https://dx.doi.org/10.24093/awej/elt1.10.

[33] Deng, L., Ku, K. and Kong, Q, "Examining predictive factors and effects of in-class multitasking with mobile phones", Interactive Technology and Smart Education, vol. 16, no. 1, pp. 49-58, 2019. https://doi.org/10.1108/ITSE-082018-0056.

[34] Buabeng-Andoh, C, "New technology in health education: Nursing students' application of mobile technology in the classroom in Ghana", Interactive Technology and Smart Education, vol. 15, no. 1, pp. 46-58, 2018. https://doi.org/10.1108/ITSE-09-2016-0039.

[35] Crompton, H, "Moving toward a mobile learning landscape: presenting an m-learning integration framework", Interactive Technology and Smart Education, vol. 14, no. 2, pp. 97-109, 2017. https://doi.org/10.1108/ITSE-02-2017-00 18.

[36] Calabrich, S. L "Learners' perceptions of the use of mobile technology in a task-based language teaching experience", International Education Studies, vol. 9, no.12, 2016. http://dx.doi.org/10.5539/ies.v9n12p120.

[37] Nalliveettil, G. M. \& Alenazi, T. H, "The impact of mobile phones on English language learning: Perceptions of EFL undergraduates", Journal of Language Teaching and Research, vol.7, no.2, pp. 264-272, 2016. DOI: 10.17507/j1tr.0702.04.

[38] Meishar-Tal, H . and Ronen, M, "Experiencing a Mobile Game and its impact on Teachers' Attitudes towards Mobile Learning", Proceedings of $12^{\text {th }}$ International Conference on Mobile Learning, pp, 35-4, Vilamoura, Algarve, Portugal, April 9 - 11, 2016. https://files.eric.ed.gov/fulltext/ED5714 36.pdf.

[39] Dashti, F. A. \& Aldashti, A. A, "EFL college students' attitudes towards mobile learning", International Education Studies, vol. 8, no. 8, pp. 13-20,2015. http://dx.doi.org/10.5539/ies.v8n8p13.

[40] Demouy, V., Jones, A., Kan, Q., Kukulska-Hulme, A. \& Eardley, A, "Why and how do distance learners use mobile devices for language learning? “, The Eurocall Review, vol. 23, no.2, pp. 10- 24, 2015. DOI: https://doi.org/10.4995/eur ocall.2016.5663.

[41] Ghrieb, E. B. “Teachers' and students' attitudes towards the use of mobile assisted language learning (Unpublished Master Thesis, Faculty of Arabic Language Arts and Foreign Languages, Mohamed Kheider University of Biskra, Biskra, Algeria,2015.

[42] Niño, A, "Language learners perceptions and experiences on the use of mobile applications for independent language learning in higher education", IAFOR Journal of Education, spec ed., pp.73-84, 2015. https://files.eric.ed.gov/fulltext/EJ 1100623.pdf.

[43] Kee, C. L. \& Samsudin, Z, "Mobile devices: Toys or learning tools for the $21^{\text {st }}$ century teenagers?", Turkish Online Journal of Educational Technology, vol.13, no. 3, pp.107-122, 2014. http://www.tojet.net/.

[44] Fageeh, A. A, "Effects of MALL Applications on Vocabulary Acquisition \&Motivation", AWEJ, vol.4, no..4. pp. 420-447, 2013.https://www.awej.org/images/AllIssues/ Volume4/Volume4Number4Dec2013/25.pdf.

[45] Khrisat, A. \& Mahmoud, S.," Integrating mobile phones into the EFL Foundation Year Classroom in King Abdulaziz University/KSA: Effects on achievement in General English and students' attitudes", English Language Teaching, vol.6, no.8, pp. 262-174, 2013. http://dx.doi.org/10.5539/elt.v6n8 p162.

[46] Dashtestani, R., 'EFL Teachers' and Students' Perspectives on the Use of Electronic Dictionaries for Learning English" CALL-EJ, vol.14, no.2, pp. 51-65, 2013. http://callej.org/jo urnal/14-2/Dashtestani_2013.pdf.

[47] Reinders, H, "Twenty ideas for using mobile phones in the language classroom", English Teaching Forum, vol,48, no.3, pp., 20-25, 2010. https://americanenglish.state.gov/files/ae/r esource_files/48_3_4_reinders.pdf.

[48] Begum, R, "Prospect for Cell Phones as Instructional Tools in the EFL Classroom", English Language Teaching vol.4, no.1.http://www.ccsenet.org/journal/index.php/elt/article/vi ew/6958/6939.

[49] Shohel, M; Mahruf C and Power, T, "Introducing mobile technology for enhancing teaching and learning in Bangladesh: teacher perspectives", The Journal of Open, Distance and e-Learning, vol. 25, no. 3, pp. 201-215, 2010. https://doi.org/10.1080/02680513.2010.511953.

[50] Yin, R. K, "Qualitative research from start to finish", New York: Guilford Publications, 2015. p.177.

[51] Krippendorff, K, "Content Analysis: An Introduction to Its Methodology", 2nd ed., Thousand Oaks, CA: Sage,2004. 